Original Research Article

\title{
Well-being of rural households around Ikere-Gorge dam in Oyo State, Nigeria
}

\author{
*Nathaniel Siji Olutegbe, Janice Elaine Olawoye, Olutokunbo Birdies Oyesola \\ Department of Agricultural Extension and Rural Development, University of Ibadan, Nigeria
}

\section{Correspondence to:}

N. S. Olutegbe, Ph.D, Department of Agricultural Extension and Rural Development University of Ibadan, Nigeria; e-mail: siji004u@yahoo.com

\begin{abstract}
The study investigated the well-being of rural households around Ikere-Gorge dam operated in South-western Nigeria. Ninety rural households were sampled in four communities, using a multistage sampling procedure. Data were analysed using frequency counts, percentages, means and Pearson Product Moment Correlation (at $\alpha_{0.05}$ ). Majority of the household heads were males (84.4\%), married (86.7\%), Christians (56.7\%), had no or primary education (74.5\%) with average age of $42.28 \pm 7.63$ years. Marginalization by government (91.1\%), elite capture of support services (90.0\%) and lack of extension services (83.3\%) were rated major constraints to livelihood by majority. The dam served benefits such as availability of water for domestic use $(\bar{x}=2.83)$, improved socioeconomic development $(\bar{x}=2.56)$, and recreational and tourism services $(\bar{x}=2.42)$. Both quality of life $(\bar{x}=1.73)$ and health $(\bar{x}=1.88)$ indicators of well-being were generally low. Constraint to livelihood had a significant relationship $(\mathrm{r}=-0.323)$ with respondents' overall well-being. The study concluded that households around dams are faced with multi-dimensional challenges at varying degrees, with negative implications for livelihood and well-being of rural households.
\end{abstract}

Keywords: dams; quality of life; health status; livelihood; assets; well-being; socioeconomic development

\section{INTRODUCTION}

One of the most widely recognised facts about agricultural production is its dependence on water, as it is essential for an efficient physiological functioning of both crops and livestock. However, due to the seasonal nature of its availability for agricultural production, as well as continued increasing exploitation in the last century all over the world (Umaru et al., 2001), human beings have devised several means of making water available all year round for crop and livestock production. One important technology that has over the years been used to achieve this is the dam. Dam has been defined and categorised in different ways. It is a barrier that is built across a stream in order to hold back water and make it available for human use.

Nigeria has made much progress in the past few decades, ranking fourth among African nations with the highest number of dams. Dams are primarily operated and managed by River-Basin Development Authorities (RBDAs) in Nigeria. One of such dams is the Ikere-Gorge, being among the eleven dams, under the control of Ogun-Osun River Basin and Rural Development Authority, Nigeria, and the largest of the only three which have residents around, dependent on them for different livelihood options. It has a storage capacity of $565 \times 106 \mathrm{~m}^{3}$ (O-ORBDA, 1998). The dam was established to serve different purposes ranging from water supply for different domestic functions, improved livelihood activities in the form of irrigation for improved crop production in Oke-Ogun area and even beyond. While it can be argued that the dam has not achieved a number of these purposes, it has been a means of livelihood for households in surrounding communities, and such include fishing,

(C) AUTHORS 2021.

This work is licensed under the Creative Commons Attribution-NonCommercial-NoDerivs 4.0 License (https://creativecommons.org/licenses/by-nc-nd/4.0/) 
crop farming and related activities. Possible benefits also include opening up of other labour opportunities, improvement of farming and commercial activities, and transformation of the river flow regime, among others, with potentials of transforming the socioeconomic life of the rural dwellers. Haruna et al. (2010) highlighted other benefits envisaged from dam construction as improved fishing activities, infrastructural facilities such as health facilities, roads, modern housing, electricity and water supply to the inhabitants.

However, dams rarely achieve the intended purposes, without constituting some negative consequences alongside the benefits, and these have been widely reported (World Commission on Dams, WCD, 2000; Ogbeibu, 2002; Ofoezie, 2002; Haruna et al., 2010; Mudzengi, 2012). The benefits and other associated livelihood related challenges have the tendencies to influence the peoples' subjective well-being rating. While it is expected that the opportunities associated with the dam will enhance their well-being, the challenges will most predictably push the well-being in the negative direction. The intended well-being of households can only be ensured and sustainably, if only the benefits address and meet the needs of the people and outweigh the effects of associated challenges. However, the extent to which this nexus has been established has been sparsely reported, for which this study was conducted. Moreover, in spite of the associated constraints and livelihood-threatening challenges, cases of in-migration on temporary and permanent basis are not uncommon in communities around such a facility as this could be an indication of improved livelihood.

Well-being has been defined as the balance point between an individual's resource pool and the challenges faced (Dodge et al., 2012). For the purpose of this study, it has been defined as the condition of a household that is reflected in levels of satisfaction with major aspects of life, members having experienced the challenges and opportunities that their immediate environment offers. The study therefore investigated well-being of the people, using life satisfaction index (OECD, 2013). The following specific objectives were pursued with respect to households around Ikere-Gorge dam: ascertain the socioeconomic characteristics and statistical relationship with well-being; examine the perceived socioeconomic benefits of the dam and how significantly related are benefits to household well-being; assess the livelihood activities/diversities and statistical relationship with well-being; describe the perceived constraints to livelihood and how significantly related constraints are to well-being; and assess the well-being of rural households around Ikere-Gorge dam in the study area.

\section{MATERIALS AND METHODS}

The study was carried out in Oyo State, and specifically in proximate communities to Ikere-Gorge dam. The reservoir is a man-made lake, located in upper Ogun River 8 kilometres east of Ikere village and $40 \mathrm{~km}$ North East of Iseyin in Oyo State, Nigeria. Ikere-Gorge reservoir takes its source between longitude $8010^{1}$ and $8020^{1} \mathrm{E}$ and latitude $3040^{1} \mathrm{E}$ and $3050^{1} \mathrm{~N}$. The reservoir has a storage capacity of $565 \times 106 \mathrm{~m}^{3}$. The reservoir was constructed by the Ogun-Osun River Basin Development Authority in 1990. It was constructed primarily for the following purposes: Provide water to Iseyin, Okeho, and Iganna and environs; supplement water supplies to Abeokuta and Lagos; provide irrigation water for 12,000 ha; and generate 6 megawatt of hydro-electricity. Also, about $90 \%$ of the people from eleven villages around the reservoir have fishing as their primary occupation, whereas farming and fish processing are other common livelihood activities (O-ORBDA, 1998). A two-stage sampling procedure was used to selected households for the study. Four communities (out of eleven) were selected from within the catchment area of the dam, using simple random sampling technique in the first stage. The communities selected are Gate, Spillway, Afonja and Dobe. In the second stage, fifty five percent of the households were then also sampled across the four communities using a simple random sampling technique. This gives a total sample size of ninety households. A total of 90 households were sampled, and household heads form the unit of analysis for the study.

Well-being was measured subjectively using the two main indicators of quality of life and health status as proposed by the Organisation for Economic Cooperation and Development (OECD, 2013), using individual subjective rating approach. The 10-point scale of the OECDs was, however, adjusted to a 5-point rating scale so as to facilitate ease of understanding of the scale among respondents, majority of whom have a relatively low level of formal education. Respondents rated each indicator on a five-point rating scale indicating their satisfaction, where 0 represents none satisfaction and 4, complete satisfaction, with mean score of each item computed. A total of 14 and 10 items represent each domain, respectively. Household well-being score, a reflection of members' level of satisfaction across the items was obtained and the mean score computed and used as the benchmark for categorising households into high and low well-being. 
Table 1. Socioeconomic characteristics of respondents in the study area $(\mathrm{n}=90)$

\begin{tabular}{|c|c|c|}
\hline Variables & Percentage & Mean \pm SD \\
\hline \multicolumn{3}{|l|}{ Age } \\
\hline$\leq 30$ & 4.4 & \multirow{5}{*}{$43.28 \pm 7.63$} \\
\hline $31-40$ & 36.7 & \\
\hline $41-50$ & 45.6 & \\
\hline $51-60$ & 11.1 & \\
\hline $61-70$ & 2.2 & \\
\hline \multicolumn{3}{|l|}{ Sex } \\
\hline Male & 84.4 & \\
\hline Female & 15.6 & \\
\hline \multicolumn{3}{|l|}{ Religion } \\
\hline Christianity & 56.7 & \\
\hline Islam & 42.2 & \\
\hline Traditional & 1.1 & \\
\hline \multicolumn{3}{|l|}{ Marital status } \\
\hline Single & 13.3 & \\
\hline Married & 86.7 & \\
\hline \multicolumn{3}{|l|}{ Educational status } \\
\hline No formal education & 38.9 & \\
\hline Primary & 35.6 & \\
\hline Secondary & 24.4 & \\
\hline OND/NCE & 1.1 & \\
\hline Indigenes & 2.2 & \\
\hline \multicolumn{3}{|l|}{ Number of years spent } \\
\hline$\leq 10$ & 21.1 & \multirow{4}{*}{$12.79 \pm 4.32$} \\
\hline $11-20$ & 45.6 & \\
\hline $21-30$ & 2.2 & \\
\hline $31-40$ & 0.0 & \\
\hline
\end{tabular}

\section{Estimated monthly income (Naira)}

\begin{tabular}{lrl}
\hline$\leq 10000$ & 22.2 \\
$10001-20000$ & 58.9 & \\
$20001-30000$ & 8.9 & \\
$30001-40000$ & 5.6 & \\
$40001-50000$ & 4.4 & \\
\hline Household size & & \\
\hline $1-5$ & 72.2 & \\
$6-10$ & 25.6 & $4.32 \pm 4.32$ \\
$11-15$ & 2.2 & \\
\hline
\end{tabular}

Perceived benefits from dam were also measured on a four-point scale of 'high', 'moderate', 'low' and 'not a benefit', with scores of 3,2, 1 and 0 , respectively. Livelihood-threatening constraints were also measured on a three-point scale of 'major', 'minor' and 'not a constraint' to a list of 16 items. Scores of 2, 1 and 0 were also assigned, respectively, and weighted mean values were used to rank the constraints in order of importance. Research instrument was subjected to face and content validity. Pre-test interview schedule was administered on rural households around Asejire dam
Table 2. Distribution of respondents based on livelihood activities engaged in $(n=90)$

\begin{tabular}{lc}
\hline Livelihood Activities & $\%$ \\
\hline On farm* & 94.4 \\
\hline Arable crop farming & 3.6 \\
Cattle rearing & 23.5 \\
Other livestock & 84.3 \\
Fishing & 1.1 \\
Fish farming (cage) & 0.0 \\
\hline Fish farming (ponds) & 12.2 \\
\hline Off farm* & 92.2 \\
\hline Cassava processing & 0 \\
\hline Processing of fish & 1.1 \\
\hline Hunting & 23.5 \\
\hline Collection of NTFPs & 0 \\
Charcoal production & \\
\hline Non-farm & 2.2 \\
\hline Artisan (tailoring, carpentry, etc) & 0.0 \\
\hline Okada riding & 4.4 \\
\hline Commercial car driving & 2.2 \\
\hline Local trade & \\
\hline Petty trading & \\
\hline Local formal employment & \\
\hline Public/private employment service & \\
\hline Migratory wage services & \\
\hline Multiple response options & \\
\hline
\end{tabular}

in Ikire, Osun State, which was not a part of the dams considered for the study. A Cronbach Alpha value of 0.91 was obtained and deemed sufficient to consider the instrument reliable. Weighted mean presents items in order of importance for perceived benefits, constraints and well-being. Pearson Product Moment Correlation (PPMC) was used to test the hypotheses at $5 \%$ level of significance.

\section{RESULTS}

\section{Socioeconomic characteristics of respondents}

The results (Table 1) show that $45.6 \%$ of the household heads in the communities were aged 41-50 years, with a mean age of about 43 years. Majority (84.4\%) of the household heads sampled were male. The study also reveals that majority of household members in the study area were Christians (56.7\%). No or low level of education characterised majority of household heads in the study area, with about 39\% having no formal education. Table 1 further reveals that a total of 71.1\% earned not more than twenty thousands Naira only; an equivalent of $\$ 50.75$, while mean household size was four persons. 


\section{Livelihood activities of households}

Results further reveal (Table 2) that across the various communities selected in the study, arable crop farming was the most practiced livelihood activity (94.4\%), followed by fishing (84.3\%) and processing of fish (92.2\%). The result, however, reveals a very poor representation of households in non-farm activities.

\section{Constraints to livelihood}

Result reveals that marginalization by government $(\bar{X}=1.90)$, elite capture of support services $(\bar{X}=1.88)$ and inadequate access to livelihood assets $(\overline{\mathrm{x}}=1.73)$ were the major socioeconomic challenges faced by households in the study area. Least-ranked constraints include religious bias $(\overline{\mathrm{x}}=0.54)$, ethnic discrimination $(\overline{\mathrm{x}}=0.54)$ and gender discrimination $(\overline{\mathrm{x}}=0.58)$.

\section{Perceived socioeconomic benefits of dams on livelihood activities of households}

Results reveal that increased water availability $(\overline{\mathrm{x}}=2.83)$ improved socioeconomic development $(\overline{\mathrm{x}}=2.56)$ and tourism and recreational benefits $(\overline{\mathrm{x}}=2.42)$ were the top-ranked socioeconomic benefits of the dam for households. Availability of drinkable water $(\bar{x}=1.04)$ and opportunities of cultivation of different crops with varying water needs $(\overline{\mathrm{x}}=1.10)$ were, however, the least ranked benefits.

Table 3. Percentage distribution of respondents by constraints to livelihood ( $\mathrm{n}=90$ )

\begin{tabular}{lrrrcc}
\hline Constraints & NC & MiC & MaC & Mean & Rank \\
\hline Marginalization by the government & 2.2 & 6.7 & 91.1 & 1.90 & 1 \\
Elite capture of support services & 2.2 & 7.8 & 90.0 & 1.88 & 2 \\
Inadequate access to livelihood assets & 0.0 & 26.7 & 73.3 & 1.73 & 3 \\
Inadequate training programmes & 1.1 & 26.7 & 72.2 & 1.71 & 4 \\
Lack of committed extension workers & 1.1 & 15.6 & 83.3 & 1.68 & 5 \\
Poor access to information & 0.0 & 32.2 & 67.8 & 1.68 & 5 \\
Insensitivity of the government & 2.2 & 27.8 & 70.0 & 1.68 & 5 \\
Illiteracy & 0.0 & 42.2 & 57.8 & 1.58 & 8 \\
High cost of management strategies & 0.0 & 44.4 & 55.6 & 1.56 & 9 \\
Lack of government support services & 0.0 & 66.7 & 33.3 & 1.33 & 10 \\
Inadequate fund & 2.2 & 64.4 & 33.3 & 1.31 & 11 \\
Unstable income source & 1.1 & 71.1 & 27.8 & 1.27 & 12 \\
Corruption of local leaders & 14.4 & 3.3 & 32.2 & 1.18 & 13 \\
Gender discrimination & 50.0 & 42.2 & 7.8 & 0.58 & 14 \\
Religious bias & 51.1 & 43.3 & 1.6 & 0.54 & 15 \\
Ethnic discrimination & 52.2 & 41.1 & 6.7 & 0.54 & 15 \\
\hline
\end{tabular}

$\mathrm{NC}=$ Not a constraint; $\mathrm{MiC}=$ Minor constraint $\mathrm{MaC}=$ major constraint

Table 4. Distribution of respondents based on benefits derived from the dam

\begin{tabular}{|c|c|c|c|c|c|c|}
\hline Benefits & $\mathbf{H}$ & M & $\mathbf{L}$ & NB & $\bar{x}$ & Rank \\
\hline Increased water availability for domestic use & 90.0 & 6.7 & 0.0 & 3.3 & 2.83 & 1 \\
\hline Improved socioeconomic development & 78.9 & 5.6 & 7.8 & 7.8 & 2.56 & 2 \\
\hline Recreation/tourism services & 75.6 & 4.4 & 6.7 & 13.3 & 2.42 & 3 \\
\hline Flood control benefits & 72.2 & 6.7 & 11.1 & 10.0 & 2.41 & 4 \\
\hline Irrigated crop farming & 25.6 & 80.1 & 3.3 & 1.1 & 2.10 & 5 \\
\hline All-season farming activities & 8.9 & 75.6 & 13.3 & 2.2 & 1.91 & 6 \\
\hline Enhanced and all-season fish farming activities & 8.9 & 77.8 & 2.2 & 11.1 & 1.84 & 7 \\
\hline Transportation benefits & 0.0 & 84.4 & 10.0 & 5.6 & 1.79 & 8 \\
\hline Availability of vegetable all year & 1.1 & 83.3 & 6.7 & 8.9 & 1.77 & 9 \\
\hline Enhanced/all season fishing activities & 4.4 & 81.1 & 1.1 & 13.3 & 1.77 & 9 \\
\hline Water for improved livestock production & 0.0 & 82.2 & 3.3 & 14.4 & 1.68 & 11 \\
\hline Improved livelihood activities & 1.1 & 78.9 & 5.6 & 14.4 & 1.67 & 12 \\
\hline Land improvement benefits & 3.3 & 20.0 & 71.1 & 5.6 & 1.21 & 13 \\
\hline Opportunities of cultivation of different crops with varying water needs & 1.1 & 8.9 & 88.9 & 1.1 & 1.10 & 14 \\
\hline Availability/provision of drinkable water & 0.0 & 10.0 & 84.4 & 5.6 & 1.04 & 15 \\
\hline
\end{tabular}

$\mathrm{H}=$ high, $\mathrm{M}=$ moderate, $\mathrm{L}=$ Low, $\mathrm{NB}=$ Not a benefit 


\section{Well-being of respondents}

\section{Distribution of households based on satisfaction with quality of life}

The results reveal that the households were most satisfied with the number of meals taken per day $(\overline{\mathrm{x}}=2.81)$, number of rooms per person $(\overline{\mathrm{x}}=1.91)$ and source of drinking water $(\overline{\mathrm{x}}=1.86)$. Quality of life indicators with which households were least satisfied, however, included level of access to basic infrastructure $(\overline{\mathrm{x}}=0.19)$, telephone services received $(\overline{\mathrm{x}}=0.49)$ and radio and television services received $(\overline{\mathrm{x}}=0.82)$. The grand mean value of 1.73 reveals that respondents were not satisfied on the average with any of the items indicating their quality of life.

\section{Distribution of respondents based on satisfaction with health}

The health item with which households expressed highest level of satisfaction included level of energy $(\bar{x}=2.51)$, quality of food taken $(\bar{x}=2.33)$ and dependency on medication $(\overline{\mathrm{x}}=2.22)$. The study further reveals that competency of the health personnel $(\overline{\mathrm{x}}=1.05)$, level of access to health clinic and hospitals $(\overline{\mathrm{x}}=1.43)$, and frequency of malaria infection $(\overline{\mathrm{x}}=1.79)$ were the least ranked health items. Summarily, the study reveals in Table 7 that the majority (83.3\%) of the rural dwellers around the dams have low level of well-being. This is an indication of low access to assets for improved livelihood which is essential for improved well-being.

\section{Relationship between the respondents' selected socioeconomic variables and well-being}

As stated in the respective research's specific objectives, the result of test of statistical relationship is presented in Table 8. It reveals that well-being had no significant relationship with respondents' socioeconomic characteristics such as age $(r=-0.156)$, household size $(\mathrm{r}=-0.142)$ and years of residence $(\mathrm{r}=0.028)$. The result, however, shows a negative and significant relationship between each of respondents' livelihood diversities $(\mathrm{r}=-0.214)$, constraints $(\mathrm{r}=-0.323)$ and well-being .

Table 5. Quality of life ratings of households around Ikere-Gorge dam

\begin{tabular}{lcc}
\hline Quality of life indicators & Mean & Rank \\
\hline Number of meals taken per day & 2.81 & 1 \\
Quality of walls of the house & 2.02 & 2 \\
Number of rooms per person & 1.91 & 3 \\
Source of drinking water & 1.90 & 4 \\
Housing unit type & 1.86 & 5 \\
Type of toilet facility & 1.82 & 6 \\
Household economic state & 1.72 & 7 \\
Quality of roofing material & 1.72 & 7 \\
Means of transportation & 1.48 & 9 \\
Radio and television services & 0.82 & 10 \\
Ease of payment of bills (electricity water, school fees) & 1.01 & 10 \\
Ease of payment of house rent & 0.70 & 12 \\
Telephone service received & 0.49 & 13 \\
Level of access to basic infrastructures & 0.19 & 14
\end{tabular}

Grand mean $=1.73=$ not satisfied

Table 6. Health well-being of rural households across Ikere-Gorge dam

\begin{tabular}{lcc}
\hline Health indicators & Mean & Rank \\
\hline Your level of energy & 2.51 & 1 \\
Quality of food taken & 2.33 & 2 \\
Dependency on medication & 2.22 & 3 \\
How well you sleep & 2.01 & 4 \\
Cumulative fitness level & 1.99 & 5 \\
Frequency of malaria infection & 1.79 & 6 \\
Frequency of other diseases' infection & 1.78 & 7 \\
Amount of sleep you get & 1.71 & 8 \\
Level of access to health clinic/hospitals & 1.43 & 9 \\
Competency of health personnel available & 1.05 & 10 \\
\hline
\end{tabular}

Grand mean $=1.89$ 
Table 7. Level of well-being of rural households

\begin{tabular}{lccccc}
\hline Level & \% & Minimum & Maximum & Mean & SD \\
\hline Low & 83.3 & 0.00 & 94.00 & 55.69 & 18.43 \\
High & 16.7 & & & \\
\hline
\end{tabular}

Table 8. Relationship between respondents' socioeconomic variables and well-being

\begin{tabular}{lccc}
\hline Variables & $\mathbf{R}$ & $\mathbf{P}$ & Decision \\
\hline Age & -0.156 & 0.143 & Not significant \\
Household size & -0.142 & 0.182 & Not significant \\
Years of residence & 0.028 & 0.832 & Not significant \\
Livelihood activities & $-0.214^{*}$ & 0.043 & Significant \\
Perceived socioeconomic benefits & 0.055 & 0.606 & Not significant \\
Constraints & $-0.323^{* *}$ & 0.002 & Significant \\
\hline
\end{tabular}

\section{DISCUSSION}

The result of age distribution of respondents implies that household heads were relatively young, which thus presents them as agile and able-bodied population who are in their productive ages. The result is consistent with the reports of Fabusoro et al. (2010) and Oyesola and Ademola (2011) who reported that majority of the labour force in rural areas of Southwest Nigeria were of ages between 20-55 years. This is expected to have a positive effect on their livelihood activities as this should translate to improved well-being of household members. The result further implies male dominance over female in household headship across the study area. The result hence agrees with Idowu (2013) who reported more male household heads of active productive age in the rural areas of Southwest Nigeria than females. The result which shows low educational status among majority suggests that a good number would be represented in the informal sector as peculiar to the ecological characteristics of the area. The study presents the communities as having access to nominal income sources with very weak economic prospects, and an indication that majority live below poverty level. This result is in line with Varrella (2020) who averred that income level is low among majority in the rural communities of Nigeria. Average household size was four persons, a relatively small size. This result may not be unconnected with poor human asset base and low, or even non-availability of family labour for use in prosecuting various livelihood activities. This is consistent with reports that households averaged about three members in rural areas of South-western Nigeria (Ewebiyi, 2014).

The result of livelihood activities (Table 2) implies that on a general note, and in spite of the various opportunities that rural households could explore, other than farming, less attention has been drawn towards exploring these alternatives. This is in spite of dwindling agricultural activities and productivity as have been widely reported due to inadequate supports from the government. The result also agrees with Adesugba and Mavrotas (2016) that the majority of Nigerians living in the rural areas are engaged either directly or indirectly in agriculture. Further, it implies that the dam serves as a source of livelihood improvement due to economic opportunities presented such as farming and fishing activities. Results obtained on constraints to livelihood is an indication of poor access to government interventions and assets that are central to improved livelihood and hence well-being of the people. All these factors pose as limitations to the livelihood of the people. The livelihood of the rural poor as reported are commonly hampered by their lack of access to markets (Kumar and Yashiro, 2013), dependence on natural resources which is worsened by prevalence of threats, and this engenders poverty and low well-being status.

The high rating given to improved socioeconomic development as one of the benefits derived from the dam is obviously due to the fact that water from the reservoir has been beneficial for improved livestock production, irrigated crop farming and enhanced/ all season fishing activities. Availability of drinkable water and opportunities of cultivation of different crops with varying water needs identified as the least derived benefits rather implies that the dam is not at its optimum in terms of meeting people's needs. Poor income of households as earlier reported (Table 1) is therefore logically justified.

The results of well-being of households which show high rating ascribed to number of meals taken per day may not be unconnected with the majority of the people being farmers, and who hence customarily have portions of their harvests reserved for household's consumption. This may suggest high level of food 
security across households in the communities around the dam, as this is expected to have a positive effect on overall well-being. On the other hand, poor state of basic infrastructures as rated by the people is an indication that the communities around the dam may have long been cut off from the developmental activities of the state and local government which govern the area. Lack of telephone and television services are also both indications that households around the dam find it difficult to access information on marketing situations that would help in appropriate decision making on marketing of agricultural produce. This may have devastating effect on the household economy. There is no doubt that efficient telephone, radio and television services serve as instrument of communication through which farmers' access to technologies could be important for improved productivity, and with potential positive effects on well-being.

From the results, it is also apparent that respondents' health indicators of well-being are far from being satisfactory. This is rather a reflection of high prevalence of disease conditions normally associated with communities around dams (Kibret et al., 2009; WHO, 2014; Bilewu et al., 2017).

The result of the hypotheses partially disagrees with Stock and Flow theory (Headey and Weary, 1991) which proposed that differences between individuals in terms of Subjective Well-being (SWB) are sometimes due to 'stable stocks', otherwise known as stable personal characteristics. It also disagrees with earlier findings (Clark and Oswald, 2006; Smyth et al. 2010; Xing and Huang, 2017) which established a relationship between well-being and age. The study which further reveals that respondents' livelihood diversities and constraints had significant but negative relationship with subjective well-being rating implies that involvement by respondents' in a number of livelihood activities rather worsened their well-being than improve it. It simply implies that households with limited number of livelihood activities had better well-being rating. The result disagrees with the argument by proponents of rural livelihood who explained diversification as the process by which rural families construct a diverse portfolio of activities and social support capabilities in order to survive and to improve their well-being (Ellis, 1998). It, however, agrees with that of Davies (1996) who attributed such a scenario to only situation when diversification becomes a necessity rather than a choice. In this case, it suggests that households mainly diversify based on necessity. Davies (1996), in Ellis (2000), posited that diversification by choice is such that a household chooses to diversify not for survival per se but also for accumulation. This is a proactive decision and leads to upward well-being mobility. The result also agrees with Fadairo et al. (2020) who had established the negative implications of environmental changes due largely to human activities on the environment-dependent livelihood and people's well-being.

\section{CONCLUSION AND RECOMMENDATIONS}

The study concludes that although Ikere-Gorge dam has been a source of varying socioeconomic benefits to households in proximate locations, the effects of identified benefits have, however, been neutralised by the enormity of livelihood threatening constraints. This study therefore affirms earlier positions that globally, operation of dams is generally accompanied with a number of challenges which threaten the socioeconomic variables of households in proximate communities. This accounts for the reason, in the case of Ikere-Gorge dam, the identified socioeconomic benefits of the dams are of no significant consequences on well-being of households. Key of such livelihood-threatening challenges identified were lack of infrastructural facilities and other public service interventions for improved livelihood; neglect of the local communities by the local, state, and central governments; inadequate agricultural extension services; and elite capture of developmental interventions. The study also ascertained that the identified challenges were the reasons the common practice of involvement in multiple livelihood options did not translate to improved well-being, but rather worsened it. This simply implies that a number of households engaged in different livelihood activities for survival, rather than for economic and social prosperity. The study therefore recommends that:

1. Ikere-Gorge and dams with similar characteristics should be upgraded in such a way that the potential benefits are well harnessed for better socioeconomic impacts on rural households around the dam reservoir.

2. Provision of infrastructure and services are proven ways of enhancing the asset base of households, as they help add value to existing physical and human capital. Therefore, the government and other developmental agencies should invest on provision of infrastructural facilities for communities around local dams, while the existing, but non-functional ones, should be fixed for the benefits of the people in these communities.

3. Policies at the government and/or private sector levels, which aim at a sustainable and need-oriented rural development, should be locality-specific. 
This can be ensured by discriminatory, rather than generalised needs assessment, so as to identify specific felt needs of different communities, and in order of priority and urgency as may be required for specific interventions;

4. The agency in charge of provision of agricultural extension services should work towards improving extension delivery in both area of coverage and quality of services.

\section{CONFLICT OF INTEREST}

The authors declared no conflicts of interest with respect to research, authorship and publication of this article.

\section{REFERENCES}

Adesugba M., Mavrotas G. (2016): Youth Employment, Agricultural Transformation and Rural Labor Dynamics in Nigeria. IFPRI Discussion Paper 01579.

Babatunde R. O., Quaim M. (2009): Patterns of income diversification in rural Nigeria: Determinants and Impacts. Quarterly Journal of International Agriculture 48: 305-320.

Bilewu S. O. Ayanshola A. M., Salami A. W. (2017): A rapid Health Impact Assessment of the University of Ilorin dam. Nigerian Journal of Technology (NIJOTECH) 36: 235-240.

Clark A. E., Oswald A. J. 2006:"The curved relationship between subjective well-being and age," Working Papers halshs-00590404, HAL. https://ideas.repec. org/p/hal/wpaper/halshs-00590404.html

Davies S. (1996): Adaptable Livelihoods Coping with Food Insecurity in the Malian Sahel. London: Macmillan Press.

Dodge R., Daly A., Huyton J., Sanders L. (2012): The challenge of defining wellbeing. International Journal of Wellbeing 2: 22-235. doi:10.5502/ijw. v2i3.4

Ellis F. (1998): Survey Articles in household strategies and rural livelihood diversification. Journal of Development Studies 35: 11-18.

Ellis F. (2000): Rural Livelihoods and Diversity in Developing Countries. Oxford University Press, Oxford.

Ewebiyi I. O. (2014): Livelihood diversification of rural households in South-west Nigeria. An unpublished Thesis, Department of Agricultural Extension and Rural Development, University of Ibadan, Nigeria, pp. 228-231.

Fabusoro E., Omotayo A. M., Apantaku S. O., Okuneye P. A. (2010): Forms and determinants of rural livelihood diversification in Ogun State, Nigeria, Journal of Sustainable Agriculture 34: 417-438.

Fadairo O. S. Olajuyigbe S., Osayomi T., Adelakun O., Olaniyan O., Olutegbe N. S., Adeleke O. (2020): Climate change, rural livelihood and eco-system nexus: Forest communities in agro-ecological zones of Nigeria. In: W. Leal Filho et al. (Eds), African Handbook of Climate Change Adaptation. https:// doi.org/10.1007/978-3-030-42091-8_155-1

Haruna S., Kabir I., Aliyu I. K. (2010): Economic impact of dam construction, the challenge and solution to agricultural productivity in Nigeria: A case study of Tura Dam in Mashigi village, Kankara LGA, Katsina State, Nigeria. Journal of Agriculture and Veterinary Services 2: 35-44.

Headey B. W., Wearing A. J. (1991): Subjective well-being: a stocks and flows framework. In Strack F., Argyle M., and Schwarz N. (Eds): Subjective Well-being - An Interdisciplinary Perspective. Pergamon Press Oxford, pp. 49-76.

Idowu A. O. (2013): Poverty profile of rural farm households in southwest Nigeria. Agronomie Africaine 25: 309-319.

Kibret S., McCartney M., Lautze J., Jayasinghe G. (2009): Malaria Transmission in the Vicinity of Impounded Water: Evidence from the Koka Reservoir, Ethiopia. IWMI Research Report 132. Colombo: International Water Management Institute.

Kumar P., Yashiro M. (2014): The Marginal Poor and Their Dependence on Ecosystem Services: Evidence from South Asia and Sub-Saharan Africa. In: von Braun J., Gatzweiler F. (Eds) Marginality. Springer, Dordrecht. https://doi.org/10.1007/978-94-007-706 1-4_11

Mudzengi B. O. (2012): An assessment of the socioeconomic impacts of the construction of Siya Dam in the Mazungunye Area: Bikita District of Zimbabwe. Journal of Sustainable Development in Africa 14: 1-17.

Ofoezie I. E. (2002): Human health and sustainable water resources development in Nigeria: schistosomiasis in artificial lakes. Natural Resources Forum 26: 150160.

Ogbeibu A. E. (2002): Dams and Impacts on Aquatic Ecosystem: Perspectives of a Hydrologist. Paper presented to Society for Water and Public Health Protection (SWAPHEP) during a public lecture on Dams and development in Nigeria, 2002, at Benin City, Edo state, Nigeria.

Ogun-Osun River Basin and Rural Developmnt Authority (O-ORBDA) (1998): What it is, what it does, how it works. O-ORBDA, 5 p. 
Organisation for Economic Cooperation and Development (OECD) (2013): Guidelines on measuring subjective wellbeing, OECD Publishing, Paris. http://dx.doi.org/10.1787/9789264191655-en

Oyesola O. B, Ademola A. O. (2011): Livelihood in University of Ibadan Social Laboratory in Ile-Ogbo Community of Osun State, Nigeria. Journal of Human Ecology 34: 91-100.

Smyth R., Nielsen I., Zhai Q. (2010): Personal well-being in urban China. Social Indicators Research 95: 231251.

Umaru A., Ogedengbe K., Omobowale M. O. (2001): Structural failures of earth dams in Nigeria: A case study of Cham Dam in Gombe State. ARPN Journal of Engineering and Applied Sciences 5: 41-52.

Varrella S. (2020): Poverty headcount rate in Nigeria 2019, by area and household.Statistica. https://www. statista.com/statistics/1121436/poverty-headcountrate-in-nigeria-by-area-and-household/

WCD - World Commission on Dams (2000): Dams and Development: A New Framework for Decision Making, Eathscan publications Ltd, London and Sterling, VA. 404 p.
WCD - World Commission on Dams (2000): Dams and Development: A New Framework for Decision-Making. www2.worldwater.org. Accessed on $2^{\text {nd }}$ May, 2017

WHO World Health Organization (2014): World Malaria Report 2014. Geneva: World Health Organization; 2014.

Xing Z., Huang L. (2013): The Relationship between Age and Subjective Well-Being: Evidence from Five Capital Cities in Mainland China. Social Indicators Research 117: 743-756.

Received: May 1, 2019 Accepted after revisions: March 4, 2021 